\title{
The effect of fasting at different ages on growth and tissue dynamics in the small intestine of the young chick
}

\author{
Assaf Geyra, Zehava Uni and David Sklan* \\ Faculty of Agriculture, Food and Environmental Quality Sciences, Hebrew University of Jerusalem, \\ PO Box 12, Rehovot 76-100, Israel
}

(Received 2 November 2000 - Revised 19 January 2001 - Accepted 6 February 2001)

\begin{abstract}
The small intestines of hatching chicks undergo rapid developmental changes in the immediate post-hatch period when the birds are making the transition from endogenous nutrient supply from yolk to dependence on exogenous feed. This transition usually only begins $48 \mathrm{~h}$ or more after hatching, owing to logistical considerations of production. The effects of fasting for $48 \mathrm{~h}$ at different times during this critical period on small intestinal development and enterocyte dynamics were examined by morphometric determinations and use of staining for proliferative-cell nuclear antigen and 5-bromo-2-deoxyuridine. The effects of fasting were specific to both time of fasting and the intestinal segment examined. Decreased development was found in the duodenum and jejunum, but was less apparent in the ileum. Fasting between 0 and $48 \mathrm{~h}$ decreased crypt size in the duodenum and jejunum, the number of crypts per villus, crypt proliferation, villus area and the rate of enterocyte migration. Fasting at later times resulted in smaller effects, although the jejunum appeared to be the most sensitive of the intestinal segments. Growth was correlated with the number of cells in the crypts, the number of cells along the villus and the segment surface area. The common practice whereby feed is first available to chicks more than $48 \mathrm{~h}$ post-hatch may depress subsequent development.
\end{abstract}

Chick: Small intestinal development: Enterocyte

In the hatching chick, as in neonatal mammals, it appears that the small intestinal mucosa is immature. At birth mammals exhibit proliferating enterocytes along the villi and have few well-defined crypts (Hermos et al. 1971). In previous studies we have indicated that a similar situation is found in the young chick (Uni et al. 1998b). However, in chicks, yolk provides an endogenous nutrient source as compared with exogenous nutrient intake in mammals. In chickens, towards the end of the incubation period residual yolk is internalized into the abdominal cavity and is the only nutrient source until exogenous food replaces it after hatch. Residual yolk at hatch comprises 20-25\% of the body weight of the chick and 10-12\% of the body weight in the poult (Noy \& Sklan, 1998). Since both turkey and chicken embryos have a wide window of hatching, commercial hatcheries do not remove birds until the maximum number of eggs hatch, and thus at exit from the hatchery the chicks average more than $1 \mathrm{~d}$ of age (Moran \& Reinhart, 1980). Hatchery treatments such as debeaking, vaccination, sexing and transport to farms result in an additional time lag before birds are given first access to food and water. Thus, most chicks are fasted for
$48 \mathrm{~h}$ or more before the first access to feed. Previous studies have indicated that this process results in a decrease in growth in the post-hatch days and lower body weights and proportion of breast muscle at marketing (Noy \& Sklan, 1998).

In laying hens $3 \mathrm{~d}$ fasting decreased duodenal villus height and similar results were observed when 45-d-old hens of a laying strain were fasted. In mammals low mucosal DNA, protein and intestinal disaccharidase and peptidase activities are found in infants with malnutrition (Heitlingher et al. 1991). Protein-energy malnutrition has been reported to reduce intestinal mass and impair epithelial proliferation and enterocyte migration in rabbits (Butzner \& Gall, 1990) and malnourished piglets had significantly lower mucosa thickness, villus height and villus surface area (Nunez et al. 1996).

The immediate post-hatch period seems to be critical for intestinal development in chicks and fasting often occurs in practice. Thus, the present study examined the effect of post-hatch fasting at different times on tissue and enterocyte dynamics in the small intestine of the chick.

\footnotetext{
* Corresponding author: Dr D. Sklan, fax +972 8 9489865, email sklan@agri.huji.ac.il
} 


\section{Methods \\ Experimental procedures}

Male broiler chicks (Ross) were obtained from a commercial hatchery (Kvuzat Yavne, Yavne, Israel) within $1 \mathrm{~h}$ of clearing the shell and were transported within $40 \mathrm{~min}$ to the facility. On arrival, chicks were weighed and assigned to four treatment groups by body weight ( $n$ 65). The first group had free access to water and to a commercial diet formulated to meet or exceed the recommendations of the National Research Council (1994) for the entire experimental period (control). The second group was maintained without access to food or water for $48 \mathrm{~h}$, after which access to food and water was as in the control group. The third group was maintained under the control conditions but had no access to feed or water from 48 to $96 \mathrm{~h}$ post-hatch. The fourth group was maintained under the control conditions but had no access to feed and water from 144 to $196 \mathrm{~h}$ post-hatch. All chicks were maintained in temperaturecontrolled brooders. Chicks were monitored daily for body weight.

All procedures were approved by the Animal Care and Ethics Committee of our institute.

\section{Labelling with 5-bromo-2-deoxyuridine}

An aqueous solution containing 5-bromo-2-deoxyuridine and 5-fluoro-2-deoxyuridine (10:1, v/v, Zymed Laboratories, San Francisco, CA, USA) was injected intraperitoneally at $1 \mathrm{ml} / 100 \mathrm{~g}$ body weight. Five injections were performed at $24 \mathrm{~h}, 72 \mathrm{~h}$ (control and 0-48 h fast), $120 \mathrm{~h}$ (control, 0-48 h fast and 48-96 h fast), $168 \mathrm{~h}$ (control and 48-96 h fast), $216 \mathrm{~h}$ (control and 144-196 h fast) and $264 \mathrm{~h}$ (control and 144-196 h fast) post-hatch. At 2, 12, 24, 48, 72 and $96 \mathrm{~h}$ after injection, four birds were killed and segments of approximately $2 \mathrm{~cm}$ were taken from the midpoint of the duodenum, from the midpoint between the point of bile duct entry and Meckel's diverticulum (jejunum) and midway between Meckel's diverticulum and the ileo-caecal junction (ileum). Segments were gently flushed twice with $0.9 \%(\mathrm{w} / \mathrm{v}) \mathrm{NaCl}$ to remove the intestinal contents and fixed in fresh $4 \%(\mathrm{v} / \mathrm{v})$ buffered formaldehyde.

\section{Immunohistochemical staining}

Intestinal samples were dehydrated, cleared and embedded in paraffin. Sections were cut at $5 \mu \mathrm{m}$ and placed on glass slides; for crypt examination serial sections were taken. For all assays, sections were deparaffinized in xylene and rehydrated in a graded alcohol series. For immunohistochemistry, sections were incubated in $3 \%(\mathrm{v} / \mathrm{v})$ $\mathrm{H}_{2} \mathrm{O}_{2}$ in methanol for $10 \mathrm{~min}$ to quench endogenous peroxidase. Proliferating-cell nuclear antigen-positive cells were measured by use of monoclonal anti-proliferating-cell nuclear antigen antibody followed by the use of peroxidase-ABC (Zymed PCNA staining kit, Zymed Laboratories) according to the manufacturer's directions. Incorporation of 5-bromo-2-deoxyuridine was indicated by monoclonal anti-5-bromo-2-deoxyuridine antibody followed by the use of peroxidase-ABC according to the manufacturer's directions. Counterstaining was done using haematoxylin, and slides were dehydrated and mounted in Histomount (Zymed Laboratories). Negative control slides, without the antibodies, were prepared in all experiments.

\section{Measurements}

Cell length was defined as the distance from brush-border membrane to the basolateral membrane. Villus surface area was calculated from villus height and width at half-height. Migration rate was calculated from the time of injecting 5bromo-2-deoxyuridine until the time the cells reached a defined point on the villus divided by the distance from the nearest crypt.

\section{Statistical analysis}

Data were analysed by ANOVA using the general linear models procedures (SAS ${ }^{\circledR}$ User's Guide, version 6; SAS Institute Inc., Cary, NC, USA). Significant differences between treatment means were examined by $t$ tests. Significance was assigned as a level of $P<0.05$ unless otherwise stated.

\section{Results \\ Growth}

The growth of chicks fasted during the three different periods is shown in Table 1. Fasting for $48 \mathrm{~h}$ depressed growth whenever applied; following access to feed, growth resumed parallel to that of fed chicks.

\section{Crypt cells}

The number of cells per crypt cross-section as influenced by fasting for $48 \mathrm{~h}$ at different times is shown in Fig. 1. Fasting between 0 and $48 \mathrm{~h}$ post-hatch depressed the

Table 1. Body weights of chicks either given free access to food and water (fed) or fasted at different times post-hatch

(Mean values and standard deviations)

\begin{tabular}{|c|c|c|c|c|c|c|c|c|}
\hline \multirow[b]{3}{*}{ Age (h) } & & & \multicolumn{6}{|c|}{ Fasted } \\
\hline & \multicolumn{2}{|c|}{ Fed } & \multicolumn{2}{|c|}{$0-48 \mathrm{~h}$} & \multicolumn{2}{|c|}{$48-96 \mathrm{~h}$} & \multicolumn{2}{|c|}{$144-196 h$} \\
\hline & Mean & SD & Mean & SD & Mean & SD & Mean & SD \\
\hline 0 & 49 & 1 & 49 & 1 & & & & \\
\hline 24 & 49 & 2 & 45 & 2 & & & & \\
\hline 36 & 55 & 1 & 44 & 2 & & & & \\
\hline 48 & $59^{a}$ & 2 & $41^{b}$ & 2 & $59^{a}$ & 2 & & \\
\hline 72 & $74^{a}$ & 3 & $53^{b}$ & 2 & $50^{\mathrm{b}}$ & 1 & & \\
\hline 96 & $85^{a}$ & 4 & $59^{b}$ & 3 & $47^{c}$ & 1 & & \\
\hline 120 & $94^{a}$ & 5 & $64^{b}$ & 4 & $67^{\mathrm{b}}$ & 2 & & \\
\hline 144 & $118^{a}$ & 6 & $85^{b}$ & 4 & $75^{c}$ & 4 & $118^{a}$ & 6 \\
\hline 168 & $136^{a}$ & 5 & & & $94^{\mathrm{b}}$ & 4 & $97^{\mathrm{b}}$ & 7 \\
\hline 192 & $156^{a}$ & 7 & & & $105^{\mathrm{b}}$ & 6 & $90^{\mathrm{C}}$ & 7 \\
\hline 216 & $183^{a}$ & 8 & & & & & $117^{\mathrm{b}}$ & 9 \\
\hline 240 & $197^{a}$ & 9 & & & & & $144^{b}$ & 10 \\
\hline 264 & $248^{a}$ & 10 & & & & & $175^{\mathrm{b}}$ & 11 \\
\hline 288 & $274^{a}$ & 11 & & & & & $203^{b}$ & 15 \\
\hline
\end{tabular}

a,b,c Mean values in rows with unlike superscript letters were significantly different $(P<0.05)$. 

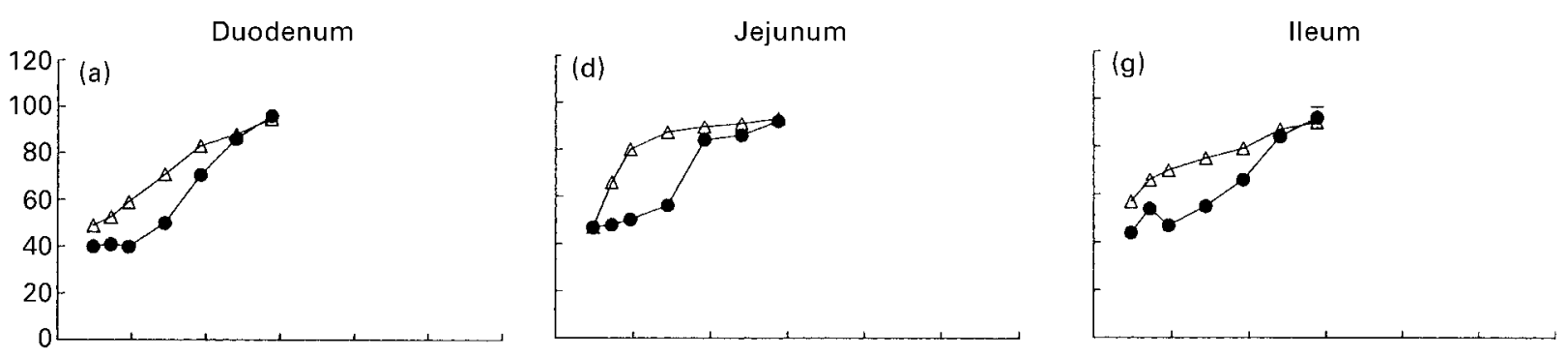

\begin{tabular}{l}
5 \\
.0 \\
0 \\
0 \\
0 \\
0 \\
0 \\
0 \\
0 \\
0 \\
0 \\
0 \\
2 \\
0 \\
0 \\
0 \\
0 \\
0 \\
\hline 0 \\
0 \\
0 \\
0 \\
0 \\
2
\end{tabular}
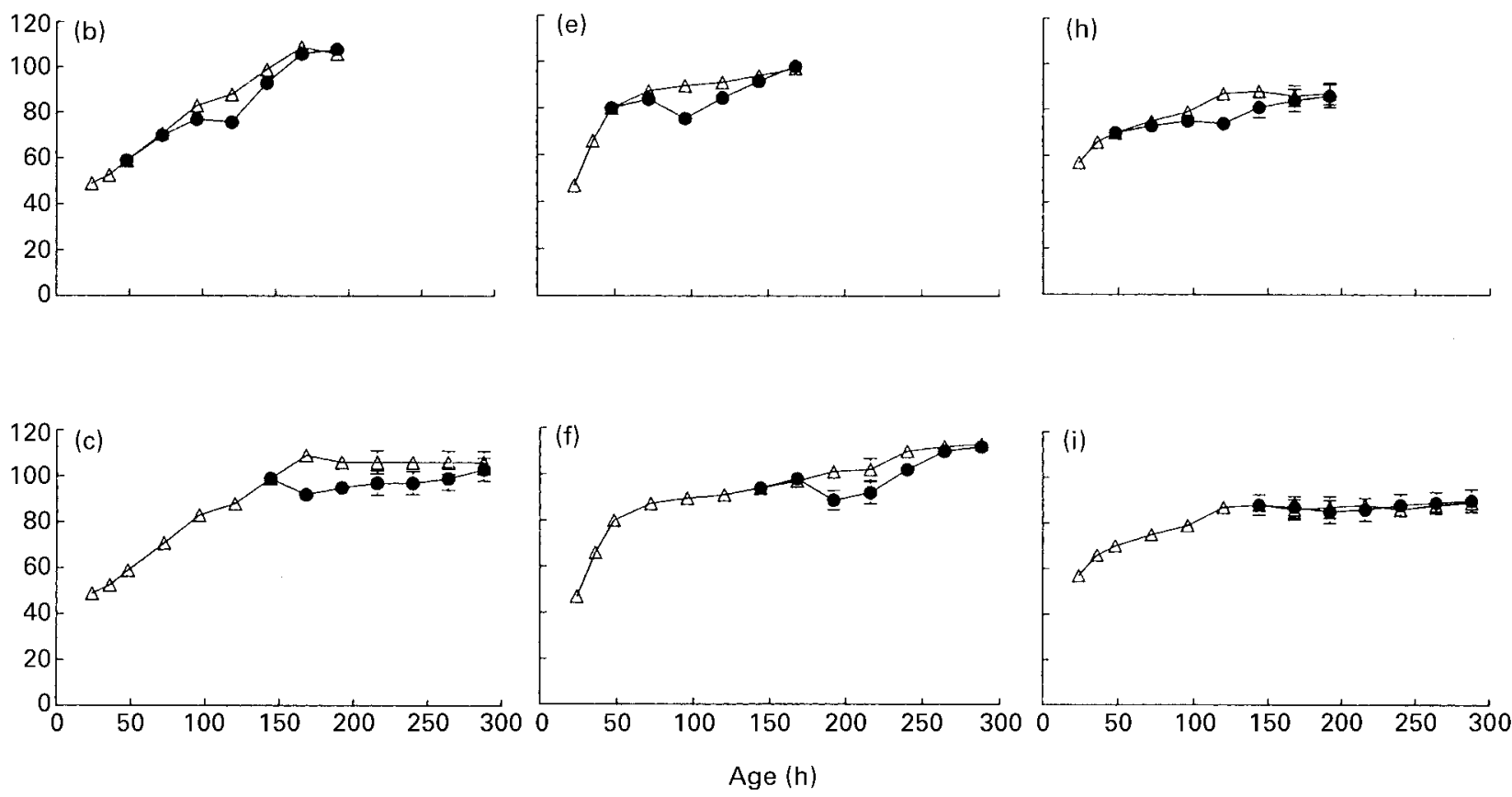

Fig. 1. Number of cells per crypt cross-section in chicks fed throughout or fasted at different times post-hatch. $(\triangle)$, fed birds; $(\bullet)$, fasted birds. (a, d, g), chicks fasted between 0 and 48 h post-hatch; (b, e, h), chicks fasted between 48 and 96 h post-hatch; (c, f, i), chicks fasted between 144 and $198 \mathrm{~h}$ post-hatch. For details of treatments and procedures, see p. 54. Values are means with their standard errors represented by vertical bars (when they do not fall within the symbols). (a, d, g), differences between fed and fasted birds were significant in the duodenum until $96 \mathrm{~h}$, in the jejunum until $72 \mathrm{~h}$ and in the ileum until $96 \mathrm{~h}(P<0.05)$. (b, e, h), differences between fed and fasted birds were significant at $120 \mathrm{~h}$ in the duodenum, at $96 \mathrm{~h}$ in the jejunum and at $120 \mathrm{~h}$ in the ileum $(P<0.05)$. (c, f, i), differences between fed and fasted birds were significant between 168 and $198 \mathrm{~h}$ in the duodenum and at $198 \mathrm{~h}$ in the jejunum $(P<0.05)$.

number of cells per crypt cross-section in all segments of the small intestine. Following feeding a gradual increase was observed in the number of crypt cells, reaching levels of the fed chicks after 4-6 d. Fasting from $48 \mathrm{~h}$ or from $144 \mathrm{~h}$ produced depressions in the number of cells per crypt, but these were smaller than those found at hatch. Refeeding resulted in recovery within 3-4 d.

\section{Percentage of proliferating-cell nuclear antigen-positive cells in the crypt}

All epithelial cells were proliferative at hatch, both in the developing crypts and along the villus in all small intestinal segments (Figs. 2 and 3). In the intestinal crypts over the first $48 \mathrm{~h}$ post-hatch the percentage of proliferating cells decreased to about 50 in crypts in all segments of the intestine (Fig. 2). Fasting for the $48 \mathrm{~h}$ post-hatch decreased the percentage of proliferating cells in the crypt to $25-40$ in all small intestinal segments. After feed was ingested this percentage increased, reaching 60-75 after $48 \mathrm{~h}$, followed by a decline towards the percentages found in fed chicks. This decline was slowest in the duodenum and most rapid in the ileum.

When chicks were fasted either between 48 and $96 \mathrm{~h}$ or between 144 and $198 \mathrm{~h}$ no decrease in the percentage of proliferating cells was found. However, on refeeding, increases in the percentages of proliferating cells were found throughout the small intestine and this increase was most pronounced in the jejunum (Fig. 2).

\section{Percentage of proliferating-cell nuclear antigen-positive cells in the villus}

All cells along the villus were proliferating at hatch in all segments of the small intestine (Fig. 3). In fed chicks this 

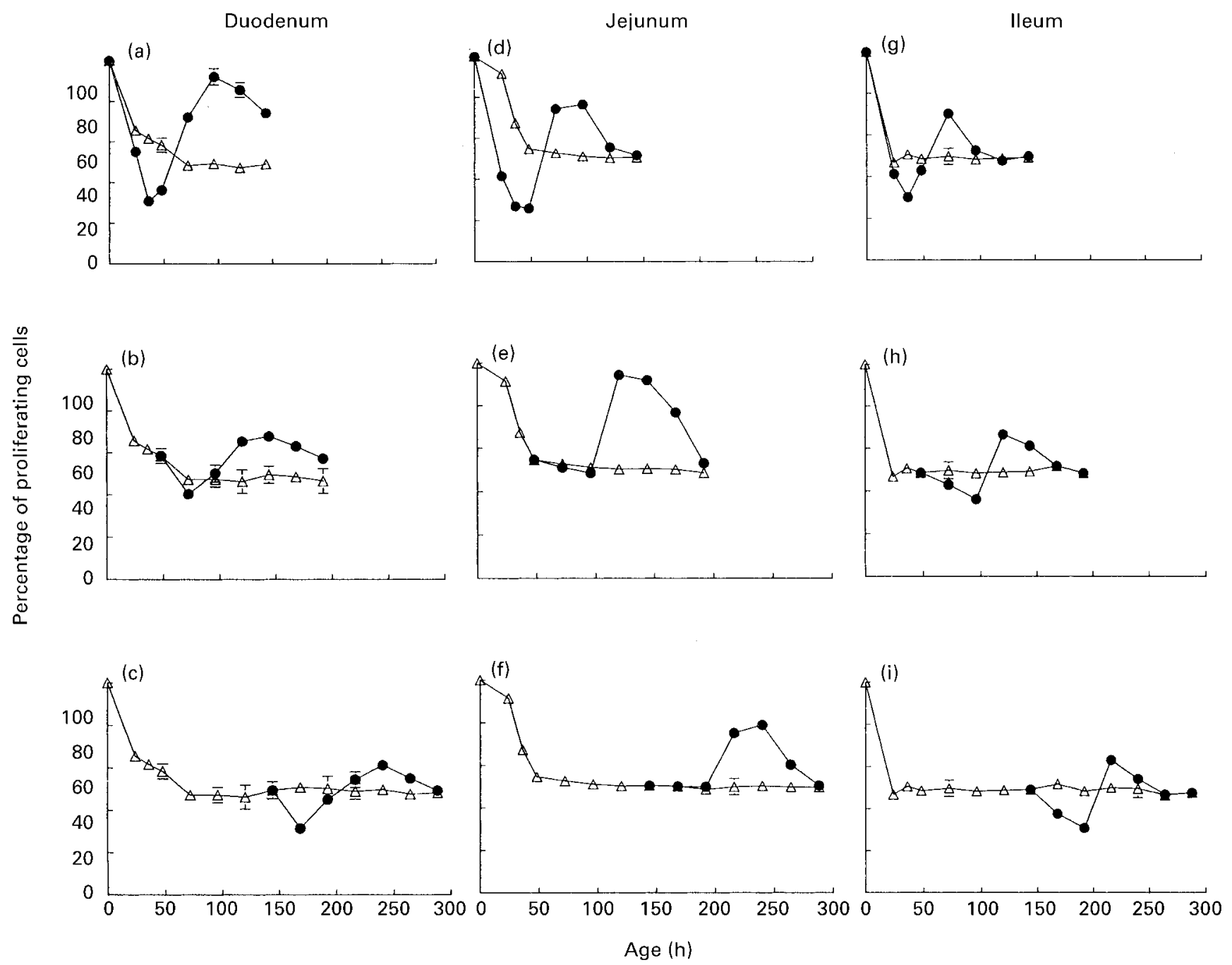

Fig. 2. Percentage of proliferating cells in the crypts in chicks fed throughout or fasted at different times post-hatch. $(\triangle)$, fed birds; $(\bullet)$, fasted birds. (a, d, g), chicks fasted between 0 and $48 \mathrm{~h}$ post-hatch; (b, e, h), chicks fasted between 48 and $96 \mathrm{~h}$ post-hatch; (c, f, i), chicks fasted between 144 and $198 \mathrm{~h}$ post-hatch. For details of treatments and procedures, see p. 54. Values are means with their standard errors represented by vertical bars (when they do not fall within the symbols). (a, d, g), differences between fed and fasted birds were significant in the duodenum from $24 \mathrm{~h}$, in the jejunum from 24 to $120 \mathrm{~h}$ and in the ileum at 36 and $72 \mathrm{~h}(P<0.05)$. (b, e, h), differences between fed and fasted birds were significant from 120 to $168 \mathrm{~h}$ in the duodenum and jejunum and at 96 and $120 \mathrm{~h}$ in the ileum $(P<0.05)$. (c, f, i), differences between fed and fasted birds were significant at 168 and $240 \mathrm{~h}$ in the duodenum, at 216 and $240 \mathrm{~h}$ in the jejunum and at 192 and $216 \mathrm{~h}$ in the ileum $(P<0.05)$.

percentage decreased with time, with a plateau of 10-20. However, the rates of decrease to these levels were slowest in the duodenum and most rapid in the ileum. Fasting for $48 \mathrm{~h}$ post-hatch initially decreased the percentage of proliferating cells in the duodenum and jejunum, and following feeding proliferation increased to approximately 40 after $96 \mathrm{~h}$ in these segments. Fasting between 48 and $96 \mathrm{~h}$ or between 144 and $198 \mathrm{~h}$ did not change the percentage of proliferating villus cells during the fasting period. However, refeeding resulted in an increased percentage of proliferating cells in the jejunum and in the ileum in chicks fasted between 48 and $96 \mathrm{~h}$ and between 144 to $198 \mathrm{~h}$.

The percentages of proliferating cells in the crypt and along the villus were linearly correlated in all intestinal segments $(r 0.70$ in the duodenum, $r 0.62$ in the jejunum, and $r 0.57$ in the ileum, Table 2).

\section{Enterocyte length}

Enterocyte length increased rapidly with age, particularly in the duodenum. Fasting decreased the rate of increase and this decrease was most pronounced during the first $48 \mathrm{~h}$ post-hatch; the effect decreased with time (data not shown).

Table 2. Correlation coefficients $(r)$ between some of the variables determined in post-hatch chicks $(n 360)$

\begin{tabular}{llccc}
\hline $\begin{array}{l}\text { Dependent } \\
\text { variable }\end{array}$ & $\begin{array}{c}\text { Independent } \\
\text { variable }\end{array}$ & Duodenum & Jejunum & Ileum \\
\hline Cells per crypt & Body weight & 0.54 & 0.63 & 0.42 \\
Cells per villus & Body weight & 0.68 & 0.89 & 0.49 \\
Surface area & Body weight & 0.95 & 0.89 & 0.73 \\
Cells per villus & Cells per crypt & 0.76 & 0.69 & 0.64 \\
Cells per villus & Surface area & 0.83 & 0.78 & 0.82 \\
\hline
\end{tabular}



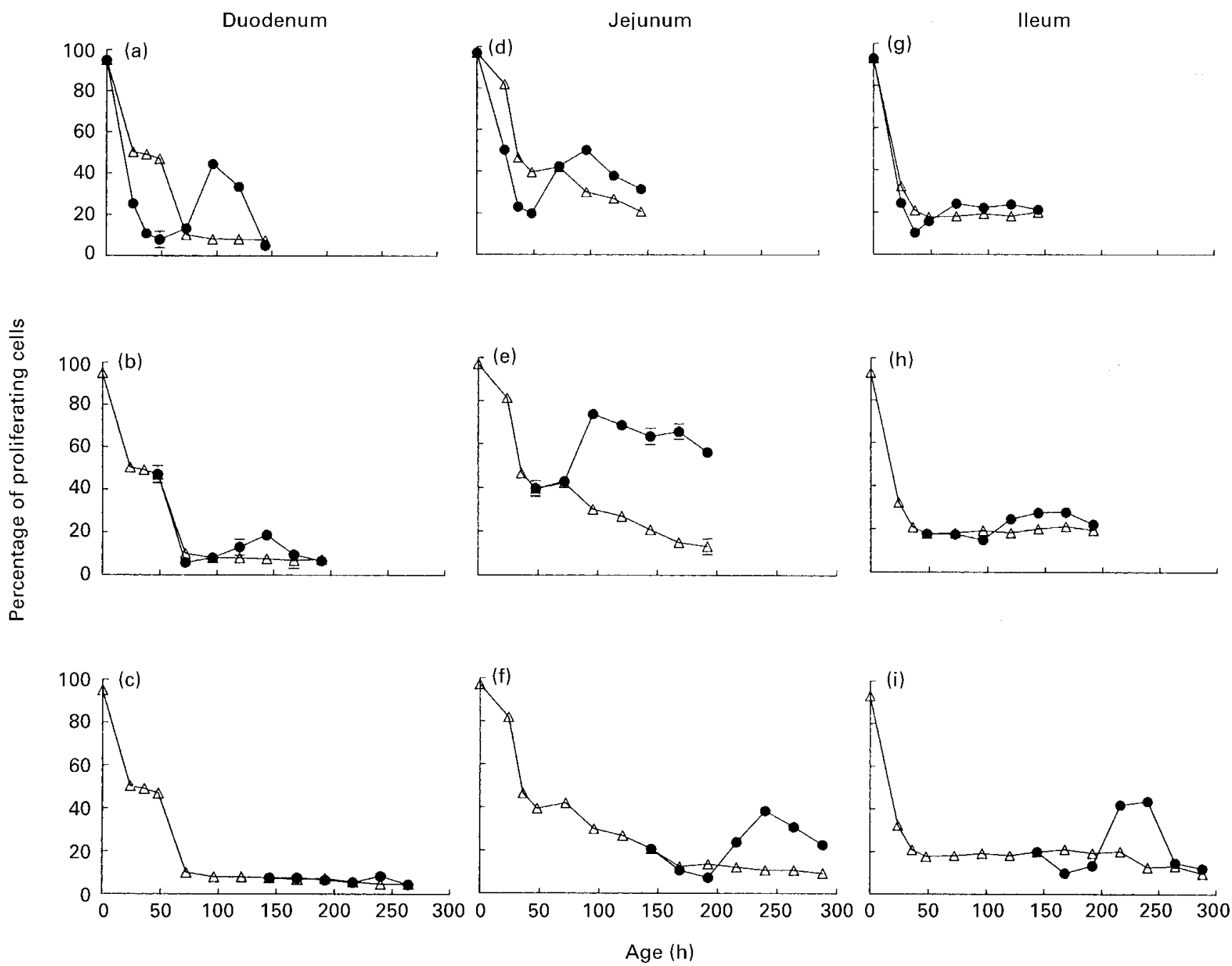

Fig. 3. Percentage of proliferating cells along the villi in chicks fed throughout or fasted at different times post-hatch. $(\triangle)$, fed birds; $(\bullet)$, fasted birds. (a, d, g), chicks fasted between 0 and $48 \mathrm{~h}$ post-hatch; (b, e, h), chicks fasted between 48 and $96 \mathrm{~h}$ post-hatch; (c, f, i), chicks fasted between 144 and $198 \mathrm{~h}$ post-hatch. For details of treatment and procedures, see $\mathrm{p}$. 54. Values are means with their standard errors represented by bars (when they do not fall within the symbols). ( $a, d, g)$, differences between fed and fasted birds were significant in the duodenum from 24 to $48 \mathrm{~h}$ and at 96 and $120 \mathrm{~h}$ and in the jejunum from 24 to $48 \mathrm{~h}$ and from 96 to $144 \mathrm{~h}(P<0.05)$. (b, e, f), differences between fed and fasted birds were significant at $144 \mathrm{~h}$ in the duodenum and from $96 \mathrm{~h}$ in the jejunum $(P<0.05)$. (c, $\mathrm{f}, \mathrm{i})$, differences between fed and fasted birds were significant from $216 \mathrm{~h}$ in the jejunum and at 216 and $240 \mathrm{~h}$ in the ileum $(P<0.05)$.

\section{Crypt:villus}

The number of crypts per villus was determined, and these increased rapidly with age in the duodenum and more slowly in the jejunum (Fig. 4). Fasting between either 0 and $48 \mathrm{~h}$ or 48 and $96 \mathrm{~h}$ depressed crypt development in the duodenum and the jejunum. Fasting between 144 and $196 \mathrm{~h}$ did not alter the number of crypts per villus. In the ileum changes with age were small and no effects of fasting were observed.

The number of crypts per villus was negatively correlated in all segments with the percentage of proliferating cells, both in the crypts and along the villus (data not shown).

\section{Villus surface area}

The villus surface area increased rapidly post-hatch, with values in the duodenum increasing most rapidly and in the ileum more slowly (Fig. 5). Fasting in the 48 h post-hatch depressed villus surface area throughout the small intestine, with the largest effect observed in the duodenum and the smallest effect in the ileum. Following feeding or refeeding, the surface area increased, initially parallel to that of villi in fed chicks and then tending towards those of fed birds after 6 d. Fasting between 48 and $96 \mathrm{~h}$ arrested the increase in villus area in the duodenum and jejunum but not in the ileum. Fasting between 144 and $198 \mathrm{~h}$ depressed the villus surface area in the duodenum but had little effect on that in the jejunum and ileum.

\section{Migration rate}

Determination of migration rate was not possible before $72 \mathrm{~h}$, owing to de novo proliferation of cells along the villi. At $72 \mathrm{~h}$ post-hatch enterocyte migration rates were similar in the 

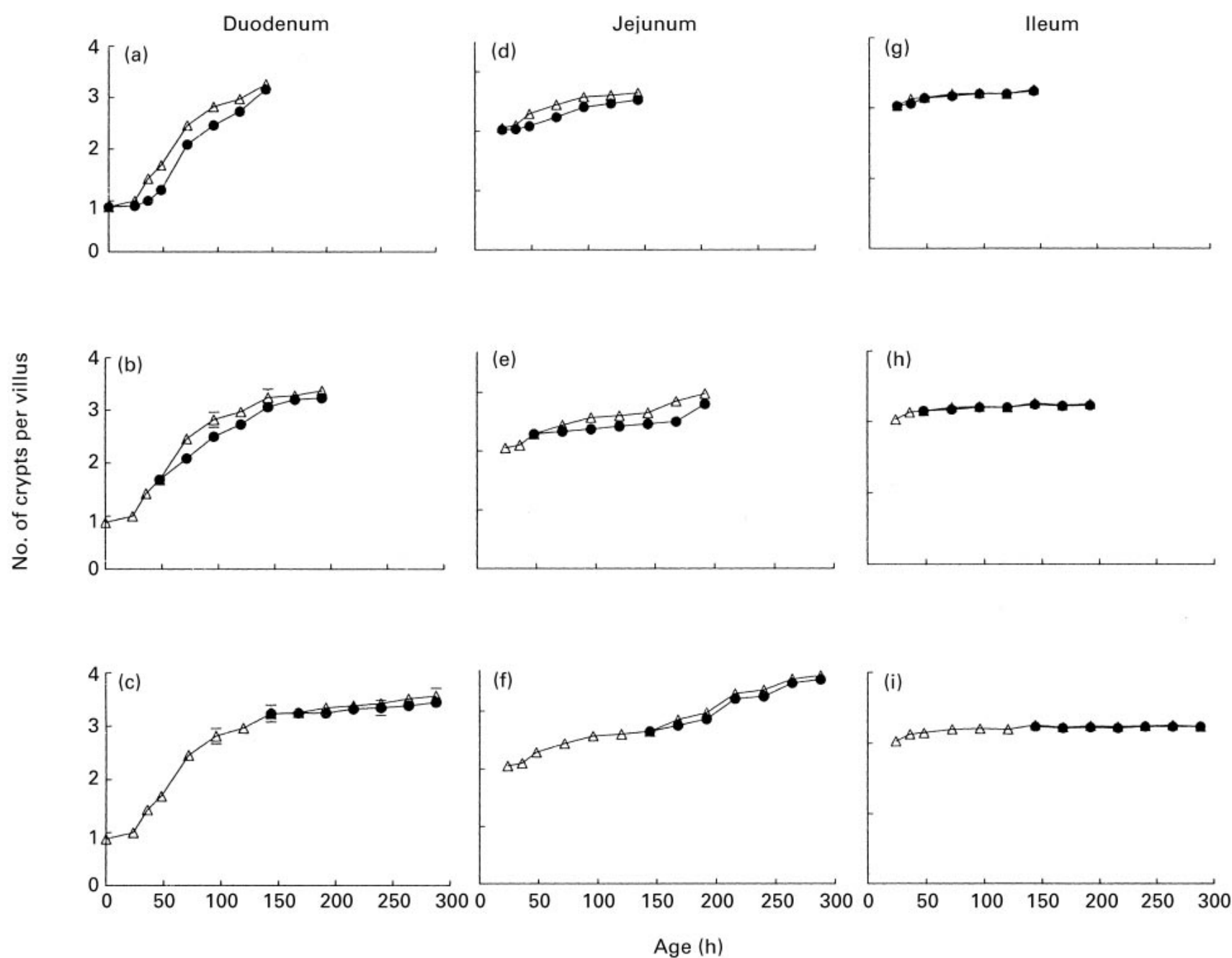

Fig. 4. Number of crypts per villus in chicks fed throughout or fasted at different times post-hatch. $(\triangle)$, fed birds; $(\bullet)$, fasted birds. (a, d, $g)$, chicks fasted between 0 and $48 \mathrm{~h}$ post-hatch; (b, e, h), chicks fasted between 48 and $96 \mathrm{~h}$ post-hatch; (c, f, i), chicks fasted between 144 and $198 \mathrm{~h}$ post-hatch. For details of treatments and procedures, see p. 54. Values are means with their standard error represented by vertical bars (when they do not fall within the symbols). (a, d, g), differences between fed and fasted were significant in the duodenum from 36 to $120 \mathrm{~h}$ and in the jejunum from 48 to $120 \mathrm{~h}(P<0.05)$. (b, e, f), differences between fed and fasted birds were significant at 72 and $96 \mathrm{~h}$ in the duodenum and from 96 to $168 \mathrm{~h}$ in the jejunum $(P<0.05)$.

duodenum and jejunum but slower in the ileum (Table 3). Fasting between 0 and $48 \mathrm{~h}$ decreased the migration rate, determined from $72 \mathrm{~h}$ in all segments, with migration rate in the fasted chicks increasing at $120 \mathrm{~h}$. Fasting between 48 and $96 \mathrm{~h}$ and between 144 and $196 \mathrm{~h}$ decreased the migration rate in the duodenum at $24 \mathrm{~h}$ after fasting, but by $72 \mathrm{~h}$ after fasting the rate had regained that of fed chicks. It was not possible to determine the migration rate in the jejunum when fasting was between 48 and $96 \mathrm{~h}$, as a large percentage of the villus cells became proliferative. However, in chicks fasted between 144 and $196 \mathrm{~h}$, the migration rate was depressed at $24 \mathrm{~h}$ after fasting. Changes in the enterocyte migration rate in the ileum were not significant in chicks fasted after $48 \mathrm{~h}$ post-hatch.

\section{Correlations}

Over the ages tested the number of crypt cells were correlated with the number of cells along a villus column in all intestinal segments (Table 2). As expected, villus surface area was correlated with the number of cells along the villus column (data not shown). Body weight was correlated with the number of cells (and the surface area) along the villus, with the number of cells in the crypt and with the surface area in all segments of the intestine (Table 2).

\section{Discussion}

Fasting is common in post-hatch chicks, owing to the logistics of production. However, the adaptive response of the small intestine to fasting influences subsequent digestive and absorptive function, and hence development (Noy \& Sklan, 1998). The small intestine is sensitive to the presence of intralumen food components (Ortega et al. 1995) and, in addition, nutrient supply from the lumen 

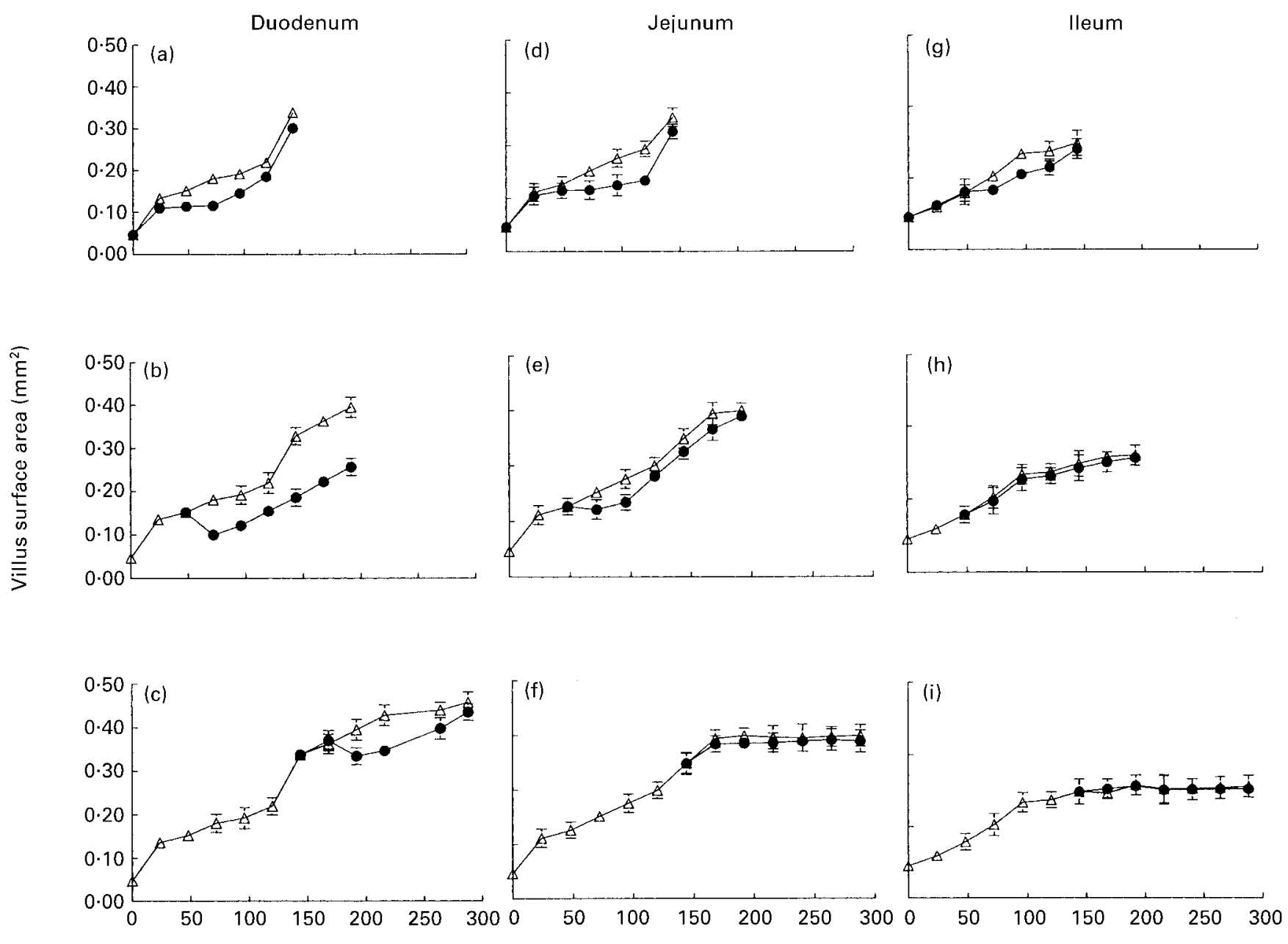

Age (h)

Fig. 5. Villus surface area in chicks fed throughout or fasted at different times post-hatch. $(\triangle)$, fed birds; $(\bullet)$, fasted birds. (a, d, g), chicks fasted between 0 and 48 h post-hatch; (b, e, h), chicks fasted between 48 and 96 h post-hatch; (c, f, i), chicks fasted between 144 and 198 h post-hatch. For details of treatments and procedures, see p. 54. Values are means with their standard errors represented by vertical bars (when they do not fall within the symbols). (a, d, g), differences between fed and fasted birds were significant in the duodenum from 48 to $120 \mathrm{~h}$ and in the jejunum from 96 to $120 \mathrm{~h}(P<0 \cdot 05)$. (b, e, h), differences between fed and fasted birds were significant from $72 \mathrm{~h}$ in the duodenum $(P<0.05)$. (c, f, i), differences between fed and fasted birds were significant from 192 to $216 \mathrm{~h}$ in the duodenum $(P<0.05)$.

plays an important role in mucosal metabolism (Reisenfeld et al. 1982; Sklan et al. 1996).

Since the small intestine develops rapidly and preferentially in chickens in the immediate post-hatch period (Uni et al. 1998a,b) the effect of fasting for $48 \mathrm{~h}$ at hatch, or at different times post-hatch, was examined in the present study. Previous studies in adult hens and in 45-d-old lightstrain chicks reported that fasting for $3 \mathrm{~d}$ decreased duodenal villus height and altered the fine structure on the villus apical surface (Yamuachi et al. 1996; Shamoto \& Yamauchi, 2000). These studies, however, only reported on changes in the duodenum. Other studies in chicks indicated that villus volume was depressed in the duodenum and jejunum by $36 \mathrm{~h}$ fasting post-hatch (Uni et al. 1998a). In the rat following $4 \mathrm{~d}$ fasting, atrophy and hypoplasia were reported in the duodenum and jejunum, but not in the ileum (Holt et al. 1986); this finding was attributed to the smaller mucosal thickness in the distal small intestine.
In the present study in post-hatch chicks, fasting retarded both body-weight increase and intestinal growth. The effects of food deprivation in each period on the tissue and enterocyte dynamics was specific in each segment and differed with time of fasting. Following feeding or refeeding, compensatory tissue responses were observed which were again specific to each segment and fasting time. All the variables examined in the present study were influenced by fasting in the initial $48 \mathrm{~h}$ post-hatch in the duodenum and the jejunum. However, in general, fasting at later stages produced smaller changes. The duodenal villus increases in size over the first weeks post-hatch in chicks, whereas the length of this segment changes little after $7 \mathrm{~d}$ (Noy \& Sklan, 1999). In contrast, jejunal and ileal villi reach a plateau after $4 \mathrm{~d}$, but increases in the size of the intestinal segment until after 2 weeks post-hatch account for most of the intestinal growth. Thus, duodenal villus surface area was depressed by starvation in all periods 
Table 3. Enterocyte migration rate $(\mu \mathrm{m} / \mathrm{h})$ in chicks either given free access to food and water (fed) or fasted at different times post-hatch* (Mean values and standard deviations)

\begin{tabular}{|c|c|c|c|c|c|c|c|c|}
\hline \multirow[b]{3}{*}{ Age (h) } & & & \multicolumn{6}{|c|}{ Fasted } \\
\hline & \multicolumn{2}{|c|}{ Fed } & \multicolumn{2}{|c|}{$0-48 h$} & \multicolumn{2}{|c|}{$48-96 \mathrm{~h}$} & \multicolumn{2}{|c|}{$144-196 \mathrm{~h}$} \\
\hline & Mean & SD & Mean & SD & Mean & SD & Mean & SD \\
\hline \multicolumn{9}{|c|}{ Duodenum } \\
\hline 72 & $6 \cdot 44^{\mathrm{a}}$ & 0.5 & $2 \cdot 59^{b}$ & 0.74 & & & & \\
\hline 120 & $6.56^{\mathrm{a}}$ & 0.34 & $5 \cdot 52^{b}$ & 0.33 & $3 \cdot 64^{c}$ & 0.47 & & \\
\hline 168 & $6.56^{\mathrm{a}}$ & 0.27 & $6 \cdot 54^{\mathrm{a}}$ & 0.29 & $6.97^{\mathrm{a}}$ & 0.47 & & \\
\hline 216 & $6 \cdot 26^{a}$ & 0.57 & $6 \cdot 24^{a}$ & 0.55 & $6 \cdot 28^{a}$ & 0.57 & $4 \cdot 01^{b}$ & 0.54 \\
\hline 264 & $6 \cdot 46^{\mathrm{a}}$ & 0.69 & $6 \cdot 44^{\mathrm{a}}$ & 0.69 & $6 \cdot 46^{\mathrm{a}}$ & 0.69 & $6 \cdot 34^{a}$ & 0.58 \\
\hline \multicolumn{9}{|c|}{ Jejunum } \\
\hline 72 & $5 \cdot 08^{a}$ & 0.48 & $3 \cdot 26^{b}$ & 0.44 & & & & \\
\hline $120^{\dagger}$ & $7 \cdot 59^{a}$ & 0.36 & $4 \cdot 12^{\mathrm{b}}$ & 0.33 & & & & \\
\hline $168^{\dagger}$ & $6 \cdot 78^{a}$ & 0.46 & $6 \cdot 7^{\mathrm{a}}$ & 0.46 & & & & \\
\hline 216 & $6 \cdot 25^{a}$ & 0.47 & $6 \cdot 20^{a}$ & 0.47 & $6 \cdot 26^{a}$ & 0.47 & $4 \cdot 87^{b}$ & 0.49 \\
\hline 264 & $6 \cdot 20^{\mathrm{a}}$ & 0.59 & $6 \cdot 12^{\mathrm{a}}$ & 0.59 & $6 \cdot 36^{a}$ & 0.59 & $7 \cdot 02^{a}$ & 0.73 \\
\hline \multicolumn{9}{|l|}{ Ileum } \\
\hline 72 & $2 \cdot 69^{a}$ & 0.33 & $1 \cdot 65^{\mathrm{b}}$ & 0.36 & & & & \\
\hline 120 & $4 \cdot 33^{a}$ & 0.22 & $2 \cdot 2^{\mathrm{b}}$ & 0.15 & $1.9^{b}$ & 0.15 & & \\
\hline 168 & $2.58^{a}$ & 0.19 & $2 \cdot 5^{\mathrm{a}}$ & 0.39 & $2 \cdot 22^{\mathrm{a}}$ & 0.39 & & \\
\hline 216 & $2 \cdot 14^{a}$ & 0.29 & $2 \cdot 13^{a}$ & 0.33 & $2 \cdot 14^{a}$ & 0.33 & $2 \cdot 05^{a}$ & 0.33 \\
\hline 264 & $2 \cdot 25^{\mathrm{a}}$ & 0.26 & $2 \cdot 28^{a}$ & 0.29 & $2 \cdot 24^{\mathrm{a}}$ & 0.29 & $2 \cdot 37^{\mathrm{a}}$ & 0.29 \\
\hline
\end{tabular}

tested, both in the present study and in previous reports (Yamuachi et al. 1996; Shamoto \& Yamauchi, 2000), as this segment was still increasing rapidly in villus size. Jejunal and ileal villus surface areas were in general less influenced by fasting, probably because in these segments the growth rate was lower.

Crypt development was retarded in all segments by fasting in the initial $48 \mathrm{~h}$ post-hatch, as indicated by the number of cells per crypt; in the duodenum and jejunum the number of crypts per villus was also depressed. Fasting later post-hatch depressed these measurements of crypt development less, probably because maturation had already occurred in the immediate post-hatch period. Ileal responses were again smaller than those of more proximal segments of the small intestine.

In the mature animal the small intestinal epithelium is continuously renewed by proliferating crypt cells that migrate up the villi. These cells differentiate and apical microvilli and absorptive functions develop during their movement towards the tip of the villi (Simon \& Gordon, 1995). However, in post-hatch chicks, as in neonatal mammals, all intestinal epithelial cells are proliferating at hatch, and within a short period proliferation is restricted mainly to the crypts (Hermos et al. 1971; Uni et al. 2000). In the present study cell proliferation both in the crypts and along the villus was sensitive to lack of feed and thus, when the chicks were fasted, fewer cells were available for crypt and villus growth. In contrast, following feeding proliferation was enhanced, thus supplying the cells required for a growth spurt, which resulted in crypt and villus sizes in fasted chicks reaching values close to those of the fed chicks after $7 \mathrm{~d}$ post-hatch. These effects were observed in the duodenum and jejunum, whereas in the ileum changes were small. Similar results have been reported in fasted adult rats, in which fasting induced quiescence within the crypt compartment, and $1 \mathrm{~d}$ after refeeding the majority of cells were stimulated to enter the cell cycle (Hodin et al. 1994, Holt et al. 1986).

Fasting from $48 \mathrm{~h}$ or from $144 \mathrm{~h}$ had little effect on proliferation along duodenal villi, whereas in the jejunum de novo proliferation of cells along the villi was dramatically enhanced. In the crypts the effect of fasting was more pronounced in the jejunum, with proliferation increasing considerably after refeeding. These observations suggest that, in order to allow rapid growth in the jejunum, enterocyte proliferation in the crypts is up regulated, and at the same time villus enterocytes return to the cell cycle and proliferate.

The rate of enterocyte migration decreased $24 \mathrm{~h}$ after fasting and increased after refeeding, with recovery more rapid when fasting was later. Previous studies reported increases in enterocyte migration rate after mucosal injury in man and rabbits (Feil et al. 1989), but effects of fasting have not been studied. Since the number of enterocytes on a villus is determined by both the rate of proliferation and the turnover rate, it appears that fasting causes a decrease in both proliferation and migration rate which would lead to fewer cells per villus and a smaller surface area. However, two mechanisms apparently exist for enterocyte production. The first is the 'classical' production in the crypts of enterocytes, which then migrate up the villus. The second is the proliferation of enterocytes on the villus itself, increasing the absorptive area without the lag time required for migration of enterocytes up the villus. The latter mechanism appears to be more dynamic in the jejunum and is activated following fasting.

The lack of food supply for $48 \mathrm{~h}$ in the post-hatch chick was expected to have differing effects in the periods examined in the present study, as yolk supplies nutrients both to the intestine and to the circulation during the immediate post-hatch period. This supply decreases exponentially with time, with little yolk remaining after $5 \mathrm{~d}$ (Noy et al. 1996). However, the period of maximal changes in the chick small intestine also seems to be in the initial hours post-hatch, although preferential growth continues with maximum intestine size for body weight at 4-8 d (Noy \& Sklan, 1999). The effects of fasting from 6 to $8 \mathrm{~d}$ were generally less dramatic than early fasting; it is possible that by this time chicks have accumulated some metabolic reserves and that they have passed the most rapid stages of development.

The hatching chick, similarly to the neonatal mammal, exhibits rapid intestinal development immediately posthatch which is sensitive to the presence of feed in the intestine. Fasting in the immediate post-hatch period depresses small intestinal enterocyte proliferation and migration, and crypt and villus development, in particular in the duodenum and jejunum. These observations indicate that early access to food is important for optimal neonatal intestinal development, and that fasting inhibits intestinal maturation. 


\section{Acknowledgements}

This work was supported in part by the Poultry Marketing Board, Tel Aviv, Israel.

\section{References}

Butzner JD \& Gall S (1990) Impact of refeeding on intestinal development and function in infant rabbits subjected to protein energy malnutrition. Pediatric Research 27, 245-251.

Feil W, Lacy ER, Wong YM, Burger D, Wenzl E, Starlinger M \& Schiessel R (1989) Rapid epithelial restitution of human and rabbit colonic mucosa. Gastroenterology 97, 685-701.

Heitlingher LA, Rossi TM, Lee P \& Lebenthal E (1991) Human intestinal disaccharidase activities: correlations with age, biopsy technique, and degree of villus atrophy. Journal of Pediatric Gastroenterology and Nutrition 12, 204-208.

Hermos JA, Mathan M \& Trier JS (1971) DNA synthesis and proliferation by villus epithelial cells in fetal rats. Journal of Cell Biology 50, 255-258.

Hodin RA, Graham JR, Meng S \& Upton MP (1994) Temporal pattern of rat small intestinal gene expression with refeeding. American Journal of Physiology 266, G83-G89.

Holt PR, Wu S \& Yeh KY (1986) Ileal hyperplastic response to starvation in the rat. American Journal of Physiology 251, G124-G131.

Moran ET \& Reinhart BS (1980) Poult yolk sac amount and composition upon placement: effect of breeder age, egg weight, sex and subsequent change with feeding or fasting. Poultry Science 59, 1521-1528.

National Research Council (1994) Nutrient Requirements of Poulry 9th ed. Washington, DC: National Academy of Science.

Noy Y \& Sklan D (1998) Metabolic responses to early nutrition. Journal of Applied Poultry Research 7, 437-451.

Noy Y \& Sklan D (1999) Energy utilization in newly hatched chicks. Poultry Science 78, 1750-1756.
Noy Y, Uni Z \& Sklan D (1996) Routes of yolk utilisation in the newly hatched chick. British Poultry Science 37, 987-996.

Nunez MC, Bueno JD, Ayudarte MV, Almendros A, Rios A, Suaarez MD \& Gil A (1996) Dietary restriction induces biochemical and morphometric changes in the small intestine of nursing piglets. Journal of Nutrition 126, 933-944.

Ortega MA, Gil A \& Sanchez-Ponzo A (1995) Maturation status of small intestine epithelium in rats deprived of dietary nucleotides. Life Sciences 19, 1623-1630.

Reisenfeld G, Geva A \& Hurwitz S (1982) Glucose homeostasis in the chicken. Journal of Nutrition 112, 2261-2266.

Shamoto K \& Yamauchi K (2000) Recovery responses of chick intestinal villus morphology to different refeeding procedures. Poultry Science 79, 718-723.

Simon TC \& Gordon JI (1995) Intestinal epithelial cell differentiation: new insights from mice, flies and nematodes. Current Opinion in Genetics and Development 5, 577-586.

Sklan D, Cohen N \& Hurwitz S (1996) Intestinal uptake and metabolism of fatty acids in the chick. Poultry Science $\mathbf{7 5}$, 1104-1108.

Uni Z, Ganot S \& Sklan D (1998a) Posthatch development of mucosal function in the broiler small intestine. Poultry Science 77, 75-82.

Uni Z, Geyra A, Ben-Hur \& Sklan D (2000) Small intestinal development in the young chick: crypt formation and enterocyte proliferation and migration. British Poultry Science 39, 544-551.

Uni Z, Platin R \& Sklan D (1998b) Cell proliferation in chicken intestinal epithelium occurs both in the crypt and along the villus. Journal of Comparative Physiology 168, 241-247.

Yamauchi K, Kamisoyama H \& Isshiki Y (1996) Effects of fasting and refeeding on structures of the intestinal villi and epithelial cells in White Leghorn hens. British Poultry Science 37, 909-921. 